ROCZNIKI TEOLOGICZNE

Tom LXVI, zeszyt 12 - 2019

DOI: http://dx.doi.org/10.18290/rt.2019.66.12-3

RYSZARD HAJDUK CSsR

\title{
MISTAGOGIA EGZYSTENCJALNA KARLA RAHNERA A PRZEPOWIADANIE SŁOWA BOŻEGO
}

\author{
EXISTENCIAL MYSTAGOGY OF KARL RAHNER \\ AND PROCLAMATION OF THE WORD OF GOD
}

\begin{abstract}
A b s t r a c t. After the Second Vatican Council, the Catholic Church pays more and more attention to mystagogy. Karl Rahner is a person who has contributed considerably to this. His appeal is to practice it in pastoral care, and a change in the method of transmitting the faith. It will disappear if people are not introduced into God's direct personal experience. Therefore, the Church, in her pastoral activity, can't limit herself to the exposition of Christian doctrine. She should show people the paths leading to life in union with God and accompany them in achieving the fullness of humanity. Also, the proclamation of the word of God is to be of a mystagogical character, that is, to reveal traces of God's presence in human reality, respond to the deepest spiritual needs of listeners and support people in making decisions about living in relationship with God. Rahner's concept of existential mystagogy doesn't negate the need for liturgical mystagogy but appeals for its close connection with everyday human existence.
\end{abstract}

Key words: pastoral care; mystagogy; preaching; experience; Christian spirituality.

Współczesny Kościół zdaje sobie sprawę z konieczności rozwoju mistagogii liturgicznej, która winna być obecna w przepowiadaniu słowa Bożego ${ }^{1}$. Służy ona wprowadzeniu ludzi w życie sakramentalne i polega na „odczytaniu

Ks. prof. dr hab. RYSZARD HAJDUK CSsR - wykładowca na Wydziale Teologicznym Uniwersytetu Warmińsko-Mazurskiego; adres do korespondencji: ul. Kardynała Stanisława Hozjusza 15, 11-041 Olsztyn; e-mail: reich-hart@wp.pl; ORCID: 0000-0002-8012-2184.

${ }^{1}$ Por. JAN PAwEe II, Ecclesia in Europa. Adhortacja apostolska o Jezusie Chrystusie, który żyje w Kościele jako źródto nadziei dla Europy, Rzym 2003, nr 73; KONGREGACJA DS. KULTU BożEGo I SAKRAMENTów, Dyrektorium homiletyczne, Rzym 2014, nr 1. 
w rytach tajemnicy Chrystusa i kontemplacji tej niewidzialnej rzeczywistości" ${ }^{2}$. Wprowadzając ochrzczonych w paschalne dzieło zbawienia, uobecniane w liturgii, mistagogia pozwala ludziom wejść na drogę wiodącą na szczyt i do źródła życia chrześcijańskiego ${ }^{3}$.

Do popularyzacji mistagogii w czasach współczesnych znacząco przyczynił się niemiecki teolog Karl Rahner SJ (1904-1984). Nie ogranicza jej jednak do wprowadzenia w misterium chrześcijańskie, celebrowane w liturgii. Według niemieckiego jezuity mistagogia to wprowadzenie człowieka w tajemnicę, którą jest on sam w swoim odniesieniu do Transcendencji. Rahner nawiązuje tym samym do mistyki św. Ignacego z Loyoli, w świetle której świat wypełniony jest obecnością Boga, a ludzkie życie i działanie są drogą prowadzącą ku Stwórcy. Działalność duszpasterska, rozwijana w duchu mistagogii, polega wówczas na tym, by pomóc człowiekowi odsłonić tajemnicę rzeczywistości, w której żyje i przypominać mu o Bogu kroczącemu z nim poprzez historię ${ }^{4}$.

Skoro Rahnerowska mistagogia - w odróżnieniu od liturgicznej zwana egzystencjalną - inspiruje działalność pastoralną, to winna znaleźć także swoje odzwierciedlenie w przepowiadaniu słowa Bożego, stanowiącym jej istotny wymiar. Chodzi wtedy o jego charakter mistagogiczny, wykraczający poza ukazywanie głębi duchowej rytów liturgicznych, czyli o wprowadzenie człowieka w tajemnicę Boga komunikującego się człowiekowi ${ }^{5}$.

\section{SPECYFIKA MISTAGOGII RAHNEROWSKIEJ}

Obserwując procesy społeczne zachodzące w powojennej Europie Zachodniej, Karl Rahner dochodzi do wniosku, iż wiara chrześcijańska w zsekularyzowanej i spluralizowanej rzeczywistości będzie zanikać, jeżeli jej głoszenie

\footnotetext{
${ }^{2}$ W. NOWAK, Eucharystia szczytem i źródtem postugi prezbitera a umiejętność jej przewodniczenia, w: Misterium Eucharystii. Teologia - liturgia - ekumenizm. Encyklika Jana Pawta II Ecclesia de Eucharistia, red. tenże, Wydawnictwo Uniwersytetu Warmińsko-Mazurskiego, Olsztyn 2004, s. 114.

${ }^{3}$ Por. E. VON SEVERUS, Mystagogie heute. Balthasar Fischer zum 80. Geburtstag, „Liturgisches Jahrbuch" 40(1992), z. 3, s. 148.

${ }^{4}$ Por. P.M. Zulehner, Pastoral: Entriegelung des Menschen, „Theologie der Gegenwart” 23(1980), z. 3, s. 10; S. KNOBLOCH, Praktische Theologie. Ein Lehrbuch für Studium und Pastoral, Herder, Freiburg i.B. 1996, s. 189.

5 Por. B. NADOLSKI, Mistagogia jako metoda w liturgii, „Collectanea Theologica" 65(1995), z. 3, s. 106; E. MAZZA, La mistagogia. Le catechesi liturgiche della fine del quarto secolo e il loro metodo, CLV, Roma 1996, s. 11.
} 
zostanie oparte wyłącznie na przekazie definicji dogmatycznych ${ }^{6}$. Nie są one już bowiem akceptowane przez wszystkich oraz nie dają już oparcia etosowi wspólnemu dla całego społeczeństwa. Prawdy chrześcijańskie przekazywane ludziom muszą znaleźć podbudowę $\mathrm{w}$ ich osobistym doświadczeniu. Jeśli nauka Kościoła przestanie być przez ludzi postrzegana jako językowa obiektywizacja doświadczenia religijnego, to wówczas jawić się im będzie jedynie jako bezużyteczna ideologia, z której można spokojnie zrezygnować, gdyż nie powoduje to żadnej istotnej zmiany w życiu.

Rahner jest przekonany, że chrześcijanin musi być „mistykiem”, tj. kimś, kto czegoś „doświadczył”, gdyż wiara chrześcijańska w przyszłości nie będzie już przekazywana jako jednogłośne, samo przez się zrozumiałe, powszechne przekonanie i jako religijny obyczaj ${ }^{7}$. Przekazywanie wiary nie może ograniczyć się do zwyczajnego wychowania religijnego czy też do jakiejś wtórnej tresury podejmowanej z uwagi na dobro instytucji religijnych. Jej miejsce winna zająć mistagogia pozwalająca człowiekowi odnaleźć właściwy obraz Boga, uformowany w oparciu o jego osobiste doświadczenia, dzięki którym odkrywa, iż w swoim bytowaniu jest całkowicie ukierunkowany na Stwórcę i Pana wszechświata.

Mistagogia egzystencjalna Rahnera opiera się na dwóch założeniach: człowiek jako tajemnica sam przez siebie wskazuje na absolutną Tajemnicę, którą nazywamy Bogiem oraz człowiek może doświadczyć podstawy swego bytu, czyli tej Tajemnicy ${ }^{8}$. Tego rodzaju doświadczenie Rahner nazywa „doświadczeniem transcendentalnym", co oznacza, że człowiek może w swoim codziennym życiu w sposób niebezpośredni, niewyraźny i beztematyczny spotkać się z podstawą swojego istnienia, czyli z Bogiem. Całe życie ludzkie jest przestrzenią umożliwiającą człowiekowi doświadczenie bliskości Boga, a nie tylko jakieś wyjątkowe momenty, w których człowiek doznaje oświecenia. Żyje on bowiem w stałym kontakcie z Bogiem w świecie wypełnionym Jego miłością. Jest to Bóg nieustannie działający zarówno w życiu ochrzczonych jak i nieochrzczonych jako ich najbardziej wewnętrzne pragnienie pełni, szczęśliwego życia, pokoju, bezgranicznej wolności i bezpiecznego dotarcia

\footnotetext{
${ }^{6}$ Por. K. RAHNER, Die grundlegenden Imperative für den Selbstvollzug der Kirche in der gegenwärtigen Situation, w: Handbuch der Pastoraltheologie, t. II/1, red. F.X. Arnold, K. Rahner, V. Schurr, L.M. Weber, Herder, Freiburg i.B. 1966, s. 270.

${ }^{7}$ Por. K. RAHNER, Schriften zur Theologie, t. VII. Zur Theologie des geistlichen Lebens, Benziger, Einsiedeln 1966, s. 22.

${ }^{8}$ Por. S. KNOBLoch, Praktische Theologie, s. 189-190.
} 
do ostatecznej przystani ${ }^{9}$. Jest On horyzontem dla wszystkich ludzkich doświadczeń. Dlatego Bóg nie pojawia się dopiero wtedy, gdy człowiek świadomie Go dostrzega w swoim życiu. Ma bowiem do czynienia z Bogiem, zanim stanie się On dla niego „tematem”10.

To beztematyczne doświadczenie ma charakter realny, ale jako rzeczywistość jest dopiero postrzegane przez człowieka, gdy nabiera wyraźnych konturów w dobrowolnie spełnianych przez niego praktykach religijnych. Dzięki nim „tak” człowieka spotyka się z „tak” Boga wychodzącego ludziom naprzeciw ze swoją łaską. Człowiek oddaje się wtedy Bogu, a Bóg człowiekowi. Wtedy też, doświadczając bliskości Stwórcy, człowiek jest w stanie podjać decyzję, czy chce żyć w zjednoczeniu z Bogiem ${ }^{11}$.

Rahner widzi, jak kolejne pokolenia coraz bardziej ogarnia fascynacja zdobyczami nauk przyrodniczych, skupiających się na fenomenach, które występują w ziemskiej rzeczywistości. Dlatego coraz trudniej przychodzi ludziom współczesnym wznieść się ponad doczesność i dokonać metafizycznego poznania Boga. Tego rodzaju poznanie może stać się udziałem człowieka, jeśli odkryje relację łączącą go ze Stwórcą „komunikującym się” światu. Takie poznanie Boga jest możliwe dzięki Jego działaniu zbawczemu w historii ludzkości i w życiu jednostek, a człowiek uzyskuje je na drodze transcendentalnej refleksji nad sobą samym ${ }^{12}$. Człowiek najpełniej poznaje siebie, gdy spotyka w swym życiu Boga.

Dla Rahnera jest rzeczą oczywistą, iż działalność Kościoła nie może być uważana za początek historii zbawienia dla konkretnych ludzi. Przekonanie to potwierdza mistagogia prowadząca ludzi do spotkania z Bogiem, który ukrywa się za tym, co niebezpośrednie, niewyraźne i bezimienne. Jako że Bóg jest obecny w codziennym życiu ludzkim jako nieskończona propozycja, milcząca miłość oraz absolutna przyszłość, nie można dostrzegać Jego obecności jedynie w przestrzeni sakralnej i w celebracji sakramentów. Jest ono bowiem możliwe również w ,goryczy codzienności”, w poszukiwaniu nadziei,

\footnotetext{
${ }^{9}$ Por. P.M. ZULEHNER, „Denn du kommst unserem Tun mit deiner Gnade zuvor... ”. Zur Theologie der Seelsorge heute. P.M. Zulehner im Gespräch mit K. Rahner, Patmos, Düsseldorf 1984, s. 57.

${ }^{10}$ Por. K. ARMBruster, Von der Krise zur Chance. Wege einer erfolgreichen Gemeindepastoral, Herder, Freiburg i.B. 1999, s. 126; H.D. EgAN, Karl Rahner. The Mystic of Everyday Life, The Crossroad Publishing Company, New York 1998, s. 36.

${ }^{11}$ Por. K. ARmbruster, Von der Krise zur Chance, s. 79-87.

12 Por. K. RAHner, Grundkurs des Glaubens. Einführung in den Begriff des Christentums, Herder, Freiburg i.B. 1977, s. 65.
} 
w podejmowaniu odpowiedzialności, w spotkaniu z miłością i śmiercią. Takie doświadczenie Boga nie jest czymś nadzwyczajnym, zarezerwowanym jakiejś wąskiej grupie mistyków. To doświadczenie może stać się udziałem każdego człowieka, otwartego na sferę nadprzyrodzoną ${ }^{13}$.

Rahner zdaje sobie sprawę, że nie ma chrześcijaństwa bez przekazu prawd wiary. Będą one jednak przyjęte przez ludzi tylko wtedy, gdy dostrzegą ich związek ze swoim osobistym doświadczeniem. Ma im w tym pomóc duszpasterstwo mistagogiczne, polegające na wprowadzeniu ich w bezpośrednie doświadczenie Boga, w którym odsłania się prawda, że jest On blisko, że można się do Niego zwracać i znaleźć w Nim schronienie, zdając się na Niego we wszystkim z całą ufnością.

Od tych, którzy chcą w Kościele pełnić funkcję mistagogów, Rahner wymaga, by nie tylko byli obeznani z teologią. Winni to być praktycy, którzy potrafia innym ukazać, jak w modlitwie nawiązywać żywą relację z Bogiem i w swojej codziennej egzystencji odkrywać to, co w świetle teologii odsłania się jako istota chrześcijaństwa ${ }^{14}$. W Rahnerowskiej mistagogii nie chodzi więc o przekazywanie ludziom określonej wiedzy, ale o stawanie razem $\mathrm{z}$ drugim człowiekiem przed Bogiem, zawsze obecnym w jego codziennym życiu ${ }^{15}$.

\section{CHARAKTERYSTYCZNE CECHY DUSZPASTERSTWA MISTAGOGICZNEGO}

Duszpasterstwo mistagogiczne opiera się na przekonaniu, że każda osoba ludzka jest przez Boga obdarzona łaską i dlatego posiada nieskończoną wartość $^{16}$. Zwraca ono swoją uwage na konkretnego człowieka i na jego doświadczenie życiowe, ucząc go spojrzenia na rzeczywistość oczami wiary. Doma-

13 Por. P.M. ZULEHNER, „Denn du kommst unserem Tun mit deiner Gnade zuvor... ”, s. 65; T. Kroll, Der Himmel über Berlin - säkulare Mystagogie?, LIT Verlag, Berlin 2008, s. 241, 235; Por. H. HASLINGER, Was ist Mystagogie? Praktisch-theologische Annäherung an einen strapazierten Begriff, w: Mystagogische Seelsorge. Eine lebensgeschichtlich orientierte Pastoral, red. S. Knobloch, H. Haslinger, Matthias-Grünewald, Mainz 1991, s. 54.

${ }^{14}$ Por. K. RAHNER, Die grundlegenden Imperative für den Selbstvollzug der Kirche in der gegenwärtigen Situation, s. 269; K. ARMBRUSTER, Von der Krise zur Chance, s. 80.

15 Por. H. HASLINGER, Sakramente - befreiende Deutung von Lebenswirklichkeit, w: Handbuch Praktische Theologie, t. II, red. H. Haslinger, Matthias-Grünewald, Mainz 2000, s. 172; T. KRoll, Der Himmel über Berlin - säkulare Mystagogie?, s. 241.

${ }^{16}$ Por. P.M. ZuLEHNER, Von der Versorgung zur Mystagogie. Theologische Implikationen seelsorglicher Praxis, „Lebendige Seelsorge” 33(1982), z. 1, s. 181. 
ga się to od duszpasterza przyjęcia postawy szacunku dla bliźniego, która stanowi nieodzowny warunek, aby można było osobie ludzkiej jako podmiotowi udzielić wsparcia w odkrywaniu prawdy o jego odniesieniu do Boga.

W duszpasterstwie mistagogicznym pierwszeństwo należy się nie jakimś ideom i zasadom, ale człowiekowi starającemu się nadać kształt swojemu życiu. Potrzebuje do tego wartości ukierunkowujących jego działania, a także musi znaleźć sens życia, aby przezwyciężyć jego kruchość oraz skończoność i móc twórczo je wypełnić czymś, co da mu poczucie szczęścia. Działanie to ma miejsce $\mathrm{w}$ codzienności przeżywanej w perspektywie Transcendencji i w poczuciu egzystencjalnej zależności od Boga. Dzięki duszpasterstwu mistagogicznemu wszystko to, co jest zaledwie jakimś doznaniem i przeczuciem, konkretyzuje się w świetle Jezusowego zaproszenia do życia w pełni (por. J 10,10), które człowiek odnajduje w komunii z Bogiem ${ }^{17}$.

Duszpasterstwo mistagogiczne przyjmuje postać towarzyszenia człowiekowi w nawiązywaniu osobistej relacji z Bogiem, która obejmuje całe ludzkie życie, je warunkuje i podtrzymuje ${ }^{18}$. Mistagog towarzyszy człowiekowi w drodze do coraz bardziej świadomego postrzegania swego odniesienia do Tajemnicy, którą dla chrześcijan jest Bóg miłujący świat i ludzi. Proces towarzyszenia może rozpocząc się wtedy, gdy duszpasterz otworzy się na problemy i pytania nurtujące człowieka. Są one bowiem zawsze punktem wyjścia do poszukiwań religijnego wymiaru ludzkich doświadczeń egzystencjalnych.

Człowiek wciąż na nowo doświadczający miłości Boga, obecnego w jego codziennym życiu, umacnia swoją wiarę. Do jej dojrzewania przyczyniają się wyzwania i konflikty, które niosą z sobą impulsy do refleksji nad sensem własnego istnienia i swoich odniesień do innych. Dzięki mistagogii człowiek przekonuje się, że gdy wypełni je Boża miłość, potwierdzają one wiarygodność wiary chrześcijańskiej ${ }^{19}$. W tego rodzaju procesie człowiek uczy się przyjmować wiarę jako coś osobistego, co działa przez miłość. Odtąd miłość Boża głoszona ludziom przez Kościół spotyka się z „miłością doświadczaną”, już obecną w ich życiư ${ }^{20}$.

\footnotetext{
${ }^{17}$ Por. Ch. Weber, Firmkatechese als Entdeckungsreise, w: Mystagogische Seelsorge. Eine lebensgeschichtlich orientierte Pastoral, s. 159; S. KNOBLOCH, Praktische Theologie, s. 192-197.

18 Por. W. Simon, Mystagogie, w: Lexikon der Pastoral, red. K. Baumgartner, P. Scheuchenpflug, Herder, Freiburg i.B. 2002, s. 175.

${ }^{19}$ Por. K. RAHNER, Die grundlegenden Imperative für den Selbstvollzug der Kirche in der gegenwärtigen Situation, s. 271.

${ }^{20}$ Por. S. KNOBLOCH, Praktische Theologie, s. 201-202.
} 
Duszpasterz, pełniący rolę mistagoga, nie może ograniczyć się do wykładu doktryny chrześcijańskiej. Jeśli w perspektywie mistagogii doświadczenie Boga może stać się udziałem człowieka tylko dzięki jego osobistemu zaangażowaniu, a nie poprzez $\mathrm{z}$ zewnątrz uzyskaną wiedzę, to znaczy, że przekaz wiary nie może przebiegać $\mathrm{w}$ formie monologu. Żaden duszpasterz nie powinien uważać siebie za kogoś, kto posiada tak wyjątkową głębię doświadczenia wiary, że jedynie on ma prawo komunikować je innym. Każdy chrześcijanin żyje bowiem w jakimś odniesieniu do Boga, a zatem posiada zdolność dokonywania doświadczeń religijnych i dlatego jest w stanie dzielić się z innymi swoim wewnętrznym bogactwem. W duszpasterstwie mistagogicznym przekaz wiary przyjmuje wówczas postać dialogu umożliwiającego międzyosobową wymianę doświadczeń duchowych ${ }^{21}$.

Mistagogia, pomagająca człowiekowi rozwinąć jego odniesienie do Transcendencji, nie ma nic wspólnego z ezoteryką i gnostycyzmem, zapewniającymi wybranym posiadanie jakichś nadzwyczajnych doświadczeń lub wiedzy tajemnej ${ }^{22}$. Podkreśla bowiem wartość modlitwy i medytacji jako dostępnych wszystkim konkretnych form urzeczywistniania się chrześcijaństwa. Dzięki nim Duch Chrystusa przenika egzystencję człowieka wierzącego i kształtuje jego postawę życiową. Ten sam Duch porusza wówczas ludzkie serca do udzielenia odpowiedzi na wezwanie Boga do życia w zjednoczeniu z Nim i do upodobniania się do Jego Syna, Jezusa Chrystusa ${ }^{23}$.

Zadaniem mistagoga jest ukazać człowiekowi sposoby wyrażania się wiary, otwierające mu dostęp do Boskiej rzeczywistości. Jednym z nich jest celebracja sakramentów, które jako rites de passage pozwalają człowiekowi zanurzyć się w tajemnicy Boga i przejść $\mathrm{z}$ normalnego porządku w porządek święty. Duszpasterstwo, prowadzone w duchu mistagogii egzystencjalnej, pomaga wierzącemu odkryć związek łączący znaki sakramentalne z jego codziennym życiem. Dzięki niej człowiek może dostrzec w rytach i tekstach liturgicznych prawdę o swojej godności i powołaniu. Sakramenty są bowiem znakami mówiącymi o Bogu działającym w świecie, który wciąż na nowo

21 Por. H. HASLINGER, Sich selbst entdecken - Gott erfahren. Für eine mystagogische Praxis kirchlicher Jugendarbeit, Matthias-Grünewald, Mainz 1991, s. 100.

22 Por. FRANCISZEK, Gaudete et exsultate. Adhortacja apostolska o powołaniu do świętości w świecie wspótczesnym, Rzym 2018, nr 36-37; M. WERnER, Krise der Korrelation und mystagogisches Handeln, „Info” 2(2003), z. 4, s. 231.

${ }^{23}$ Por. Ch. WEBER, Firmkatechese als Entdeckungsreise, s. 159-160. 
wychodzi ludziom na spotkanie, aby im pokazać, jak bardzo jest im bliski i pragnie ich szczęścia ${ }^{24}$.

\section{PRZEPOWIADANIE W DUCHU MISTAGOGII EGZYSTENCJALNEJ}

Istotą wiary chrześcijańskiej jest relacja osobowa $\mathrm{z}$ Chrystusem ${ }^{25} . \mathrm{Z}$ tego względu głoszenie Ewangelii nie jest równoznaczne z przekazywaniem nauki o istnieniu jakiegoś bezimiennego Boga, ogłaszaniem prawa moralnego lub nakłanianiem ludzi do spełniania określonych praktyk religijnych. Celem proklamacji słowa Bożego jest bowiem pomóc ludziom rozpoznać Chrystusa jako Pana i Boga, który już dawno podtrzymuje ich życie swoją uprzedzającą miłością. Głosić Ewangelię to ukazywać ludziom wydarzenie Chrystusa jako coś aktualnego, co ich osobiście dotyka. Przepowiadanie słowa Bożego musi mieć zatem charakter mistagogiczny, czyli nie tyle ma być wykładem prawd wiary i wezwaniem do nawrócenia, co opowiadaniem o tym, co podtrzymuje i wypełnia ludzkie życie, czyli świadectwem o Bożej obecności ${ }^{26}$.

Mistagogiczna posługa słowa wyrasta z wiary w zbawczą obecność Chrystusa w świecie. Zadaniem głosicieli słowa Bożego jest więc wzbudzić u ludzi świadomość, że Jezus jest obecny pośród nich i pomóc im Go dostrzec w rzeczywistości. W przepowiadaniu ludzie mogą odnaleźć wskazówki pomagające im rozpoznać, że ich istnienie już jest zanurzone w Jezusie Chrystusie. Dlatego też nie można głosić Chrystusa w oderwaniu od konkretnego ludzkiego życia, które jest miejscem urzeczywistniania się Bożego zbawienia ${ }^{27}$.

Przepowiadanie mistagogiczne służy formacji chrześcijańskiej, która nie dokonuje się pod wpływem treści pochodzących z zewnątrz. Mistagogia jest pomocą dla samopomocy, aby wesprzeć człowieka w osiąganiu pełni osobowego rozwoju. Posługa słowa pełni wówczas rolę lustra, w którym człowiek rozpoznaje siebie jako kogoś, kto może urzeczywistniać się w pełni jako

\footnotetext{
${ }^{24}$ Por. R. ZINKEVIČIŪTĖ, Karl Rahners Mystagogiebegriff und seine praktisch-theologische Rezeption, Peter Lang AG, Frankfurt a.M. 2007, s. 223.

${ }^{25}$ Por. BenedyKt XVI, Deus caritas est, Encyklika o miłości chrześcijańskiej, Rzym 2005, nr 1.

${ }^{26}$ Por. P. Hitz, Das Mysterium Christi und die Verkündigung, „Theologie der Gegenwart” 6(1963), z. 3, s. 157; K. КосH, Kirche ohne Zukunft? Plädoyer für neue Wege der Glaubensvermittlung, Herder, Freiburg i.B. 1993, s. 68; F. CACUCCI, La mistagogia. Una scelta pastorale, Edizioni Dehoniane, Bologna 2006, s. 5.

${ }^{27}$ Por. B. NAdOLSKI, Mistagogia jako metoda w liturgii, s. 109; P. HITZ, Le Mystère de l'évangélisation dans la vie des hommes, „Masses Ouvrières” 1962, nr 190, s. 22-27.
} 
osoba tylko wtedy, gdy zwraca się ku innym. A ponieważ człowiek nie może właściwie rozwinąć swojego człowieczeństwa bez Boga, potrzeba mu mistagogii odsłaniającej ślady obecności Stwórcy w świecie i wskazującej drogi do nawiązania z Nim żywej relacji. W takim kontekście przepowiadanie mistagogiczne kieruje do ludzi apel o podjęcie odpowiedzialności za swoje życie i kształtowanie go w żywej relacji z Bogiem ${ }^{28}$.

Przepowiadanie mistagogiczne winno być wpisane w posługę towarzyszenia ludziom w ich osobistym odkrywaniu bliskości Boga. Oznacza to, że współczesny mistagog nie może pouczać człowieka „z góry”, lecz winien stanąć obok niego i jego sprawy postawić w centrum. Mając przed sobą konkretnego człowieka, głosiciel słowa nie może operować jakimiś ogólnikami ani przekazywać treści wiary w taki sposób, jakoby chodziło o jakąś oderwaną od życia abstrakcyjną rzeczywistość. Co prawda, ogólniki i pojęcia abstrakcyjne nie pozwalają mówcy pozostać niemym, gdyż zawsze za ich pomocą może udzielić jakiejś odpowiedzi na ludzkie pytania i wątpliwości, to jednak może się okazać, że jego słowa nikogo nie poruszają, gdyż od ludzkiej rzeczywistości dzieli je zbyt wielki dystans ${ }^{29}$.

W przepowiadaniu mistagogicznym punktem wyjścia winien zawsze być człowiek i jego problemy egzystencjalne. Zamiast mówić słuchaczom o tym, co Kościół ma im cennego do zaoferowania, należy pozwolić im odczuć, że ich potrzeby i pragnienia mogą być spełnione dzięki temu, co przekazuje im głosiciel słowa. Gdy bowiem słuchają, zastanawiają się, co w tym jest dla nich. Mistagog musi więc mieć na uwadze potrzeby, pragnienia i zainteresowania słuchaczy, aby mógł im zaproponować właściwą pomoc w realizacji ich oczekiwań. Mówca winien zapomnieć o sobie i swoich upodobaniach, aby wypełnić swoje myśli ich preferencjami i spojrzeniem na rzeczywistość. Gdy w jego słowach wierzący rozpoznają swoje własne sprawy, nadzieje i tęsknoty, otworzą się także na przekazywane w nich wskazówki, pomagające im znaleźć w Bogu odpowiedź na najgłębsze pytania ${ }^{30}$.

Przekaz wiary może dokonać się tylko wtedy, gdy nie sprowadzi się do formułowania moralnych apeli, ale przebiegać będzie w postaci mistagogii

\footnotetext{
${ }^{28}$ Por. S. KNOBLOCH, Mystagogie und Subjektwerdung, ,Theologisch-Praktische Quartalschrift" 141(1993), z. 2, s. 153.

${ }^{29}$ Por. S. KNOBloch, Praktische Theologie, s. 195; E. FlüGGE, Der Jargon der Betroffenheit. Wie die Kirche an ihrer Sprache verreckt, Kösel, München 2016, s. 37.

${ }^{30}$ Por. A.C. RuETER, Making Good Preaching Better, Liturgical Press, Collegeville 1997, s. 28.
} 
wprowadzającej ludzi w świat duchowy ${ }^{31}$. Nie oznacza to, że należy zrezygnować z prezentowania wymagań moralnych, gdyż zachowanie chrześcijanina winno być zgodne z wyznawaną przez niego wiarą. Najpierw jednak każdy ochrzczony winien nauczyć się patrzeć na rzeczywistość oczyma ducha. Jego myśl winna wznosić się ku niebu, ku rzeczom niewidzialnym i ostatecznym, aby następnie mógł podejmować na co dzień decyzje, które będą zgodne z nauką Chrystusa ${ }^{32}$.

Głosiciel słowa, który staje przed tego rodzaju zadaniem, musi być więc „mistykiem” odkrywającym, a następnie pomagającym ludziom zobaczyć jeszcze niedostrzegalny dla nich nadprzyrodzony wymiar rzeczywistości i cel ich życia wykraczający poza doczesność. Przypomina on wówczas rzeźbiarza dostrzegającego inną rzeczywistość w jeszcze surowym, bezkształtnym kamiennym bloku, zanim przyłoży do niego dłuto, by w formie rzeźby zaprezentować ją innym. Aby być mistagogiem, trzeba zatem najpierw samemu „widzieć”, aby potem w posłudze słowa „,czynić widzialnym” dla innych ${ }^{33}$. Jest to możliwe dzięki kontemplacji pozwalającej dostrzegać działanie Boga w codziennej rzeczywistości, a następnie mówić o tym innym ${ }^{34}$.

Mistagog, który w swoim życiu widzi Boga i zna Boga, nie mówi nigdy o swoim Stwórcy, jakby był On jakimś dalekim przedmiotem, lecz jako o Kimś, z kim żyje w intensywnej relacji. Dlatego też ten, kto mówi o Bogu, w istocie rzeczy mówi o sobie. Człowiek może tylko mówić o tym, jak wygląda jego życie z Bogiem, kim jest dla niego Bóg i jak przeżywa swoją relację ze Stwórcą. Gdy ktoś mówi o Bogu, zawsze równocześnie mówi o sobie ${ }^{35}$.

Głosicielom słowa Bożego nie wolno ulec przekonaniu, że wszystko da się wyjaśnić. Z tego też względu najwłaściwszą postawą człowieka wobec tajemnicy Boga jest milczenie ${ }^{36}$. Takiej postawy domaga się mistagogia liturgicz-

\footnotetext{
${ }^{31}$ Por. K. Koch, Kirche ohne Zukunft?, s. 69.

${ }^{32}$ Por. E. MAZZA, La mistagogia, s. 132.

${ }^{33}$ Por. H.J.M. Nouwen, Clowning in Rome. Reflections on Solitude, Celibacy, Prayer, and Contemplation, Image Books, Garden City 1979, s. 87-88; P. ENDEAN, Karl Rahner and Ignatian Spirituality, Oxford University Press, New York 2004, s. 74.

${ }^{34}$ Por. FrANCISZEK, Evangelii gaudium. Posynodalna adhortacja o głoszeniu Ewangelii we wspótczesnym świecie, Rzym 2013, nr 150; Kongregacja DS. KUltu BożEGO I SAKRAMENTów, Dyrektorium homiletyczne, $\mathrm{nr} 27$.

35 Por. E. FLÜGGE, Der Jargon der Betroffenheit, s. 132-133.

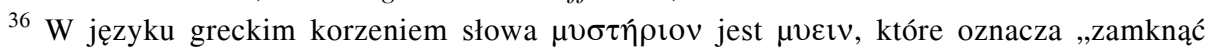
wargi”; zob. G. RAVASI, Comunicación y Palabra de Dios. Visión bíblica y teológica de la comunicación, w: Evangelización y Comunicación, red. G. Ravasi, J. McDonnell, W. Uranga, San Pablo, Caracas 1994, s. 20.
} 
na, pomagająca wierzącym dokonać przejścia od sakramentów do „misteriów"37. W liturgii ludzie wstępują bowiem w rzeczywistość, której nie da się ująć w postaci zwykłego objaśnienia czy sprowadzić do znajomości treści prawd wiary. Misterium chrześcijańskie to wydarzenie, działanie Zmartwychwstałego, życie, w którym człowiek ma udział. Dla Ojców Kościoła sama celebracja misterium Chrystusa jest już wprowadzeniem w Boże tajemnice. Liturgia włącza człowieka w misterium chrześcijańskie, gdy jest sprawowana. To właśnie w celebracji liturgicznej misterium zbawienia się objawia, komunikuje ludziom i daje się poznać w całym swym bogactwie. Wtedy to sam Bóg jest pierwszym mistagogiem, gdyż liturgia, w której zbawienie staje się obecne tu i teraz, jest przede wszystkim Jego dziełem ${ }^{38}$.

Mistagogia egzystencjalna zwraca uwagę na to, by głoszenie słowa Bożego w czasie liturgii łączyło występujące w niej symbole z codziennym życiem. Okazany w ten sposób szacunek dla ludzkich doświadczeń pomoże im popatrzeć w świetle wiary na swoją codzienność i dostrzec w niej działanie Boga. Ten sam Bóg działa w celebracji sakramentów, mówiących o Jego obietnicach, wskazujących na Jego obecność wśród ludzi i pozwalających już na ziemi zakosztować zbawienia. Tak rozumiana liturgia nie domaga się od jej uczestników, by z lekceważeniem traktowali codzienność, lecz by uczestnicząc w sprawowaniu sakramentów, jeszcze mocniej złączyli się z Tym, który nieustannie towarzyszy im $\mathrm{w}$ ich dążeniu do życia w pełni ${ }^{39}$.

Rahnerowska mistagogia egzystencjalna ma na uwadze zmiany zachodzące w sferze społeczno-kulturowej, które wpływają na sposób myślenia ludzi o sobie i o rzeczywistości. Punktem wyjścia dla mistagogicznej posługi słowa jest $\mathrm{w}$ tej perspektywie człowiek zmagający się ze swoim losem i pytający o fundamenty swojej egzystencji. Mistagogia egzystencjalna każe patrzeć nie tylko na liturgię, ale na całe życie ludzkie jako na przestrzeń działania zbaw-

\footnotetext{
${ }^{37}$ Por. Katechizm Kościoła Katolickiego, Poznań 1992, nr 1075.

${ }^{38}$ Por. J. WoŁoszKa, Celebracja sakramentu matżeństwa anamneza tajemnicy stworzenia, „Anamnesis” 8(2002), z. 4, s. 55; F. CACUCCI, La mistagogia, s. 6.

${ }^{39}$ Por. L. MöDL, Liturgie und Predigt, ,,Theologisch-Praktische Quartalschrift” 141(1993), z. 4, s. 345; B. Kranemann, Liturgie als Anstiftung zum Handeln. Die diakonale Dimension des christlichen Wortgottesdienstes, w: Die diakonale Dimension der Liturgie, red. B. Kranemann, Th. Sternberg, W. Zahner, Herder, Freiburg i. B. 2006, s. 197.
} 
czej łaski Boga. Jej adresatem nie jest już wyłącznie żywy członek Kościoła, odpowiednio uformowany duchowo i zaznajomiony $\mathrm{z}$ arkanami wiary katolickiej, ale chrześcijanin „kulturowy”, bardziej zajęty swoimi problemami egzystencjalnymi aniżeli zafascynowany zgłębianiem istoty religii Chrystusowej, a nawet każdy człowiek poszukujący prawdy i sensu życia. Praktyka pokazuje, że i ci ostatni odwiedzają dzisiaj świątynie, motywowani do udziału w celebracjach liturgicznych jakimiś wyjątkowymi okolicznościami czy zwyczajami panującymi w ich środowisku.

W swojej koncepcji mistagogii Rahner daje wyraźne pierwszeństwo doświadczeniu przed wiedzą religijną. Respektowanie tej zasady w przepowiadaniu liturgicznym sprawi, że nie zamieni się ono w instruktaż ani nie wypełni się jakąś spekulacją filozoficzno-teologiczną, wywołującą wrażenie, że Bóg jest tylko dalekim przedmiotem ludzkiej refleksji, gdyż mówi się o Nim na ambonie tak, jak opowiada się o kimś nieobecnym. Mistagogia egzystencjalna domaga się szacunku dla tajemnicy, którą jest nie tylko misterium chrześcijańskie, celebrowane w liturgii, ale także sam człowiek, relacja łącząca go z Bogiem i otaczająca go rzeczywistość. $\mathrm{Z}$ tej świadomości rodzi się u głosicieli słowa Bożego postawa zadziwienia, kontemplacji nigdy niezgłębionej tajemnicy Stwórcy i pokornej służby człowiekowi, polegającej na towarzyszeniu mu w odkrywaniu prawdy o żywym Bogu, działającym w jego życiu.

Mistagogia, proponowana przez Rahnera, nie stoi w opozycji do mistagogii liturgicznej ani nie neguje potrzeby przekazu wiedzy religijnej. Nie pozwala jednak zapomnieć o takich zasadach, jak konieczność dostrzegania Boga w całej rzeczywistości (św. Ignacy z Loyoli) i komunikowania innym owoców kontemplacji (św. Tomasz z Akwinu). Wszystko to po to, aby udział człowieka w liturgii znalazł swoją kontynuację w jego codziennym życiu ${ }^{40}$.

\section{BIBLIOGRAFIA}

ARMbruster K., Von der Krise zur Chance. Wege einer erfolgreichen Gemeindepastoral, Herder, Freiburg i.B. 1999.

BENEDYKT XVI, Deus caritas est. Encyklika o miłości chrześcijańskiej, Rzym 2005.

CACUCCI F., La mistagogia. Una scelta pastorale, Edizioni Dehoniane, Bologna 2006.

EgAn H.D., Karl Rahner. The Mystic of Everyday Life, The Crossroad Publishing Company, New York 1998.

EndeAn P., Karl Rahner and Ignatian Spirituality, Oxford University Press, New York 2004.

${ }^{40}$ Por. K. RAHNER, Schriften zur Theologie, t. VII, s. 204-220. 
FLÜGGE E., Der Jargon der Betroffenheit. Wie die Kirche an ihrer Sprache verreckt, Kösel, München 2016.

FRANCISZEK, Evangelii gaudium. Posynodalna adhortacja o głoszeniu Ewangelii we współczesnym świecie, Rzym 2013.

FrANCISZEK, Gaudete et exsultate. Adhortacja apostolska o powołaniu do świętości w świecie współczesnym, Rzym 2018.

HASLINGER H., Sakramente - befreiende Deutung von Lebenswirklichkeit, w: Handbuch Praktische Theologie, t. II, red. H. Haslinger, Matthias-Grünewald, Mainz 2000, s. 172.

HASLINGER H., Sich selbst entdecken - Gott erfahren. Für eine mystagogische Praxis kirchlicher Jugendarbeit, Matthias-Grünewald, Mainz 1991.

HASLINGER H., Was ist Mystagogie? Praktisch-theologische Annäherung an einen strapazierten Begriff, w: Mystagogische Seelsorge. Eine lebensgeschichtlich orientierte Pastoral, red. S. Knobloch, H. Haslinger, Matthias-Grünewald, Mainz 1991, s. 15-75.

Hitz P., Das Mysterium Christi und die Verkündigung, „Theologie der Gegenwart” 6(1963), z. 3, s. 153-158.

Hitz P., Le Mystère de l'évangélisation dans la vie des hommes, „Masses Ouvrières” 1962, nr 190, s. 11-48.

Jan PAWEe II, Ecclesia in Europa. Adhortacja apostolska o Jezusie Chrystusie, który żyje w Kościele jako źródło nadziei dla Europy, Rzym 2003.

Katechizm Kościoła Katolickiego, Poznań 1992.

KNOBLOCH S., Mystagogie und Subjektwerdung, „Theologisch-Praktische Quartalschrift” 141(1993), z. 2, s. 148-157.

KNOBLOCH S., Praktische Theologie. Ein Lehrbuch für Studium und Pastoral, Herder, Freiburg i.B. 1996.

KocH K., Kirche ohne Zukunft? Plädoyer für neue Wege der Glaubensvermittlung, Herder, Freiburg i. B. 1993.

Kranemann B., Liturgie als Anstiftung zum Handeln. Die diakonale Dimension des christlichen Wortgottesdienstes, w: Die diakonale Dimension der Liturgie, red. B. Kranemann, Th. Sternberg, W. Zahner, Herder, Freiburg i. B. 2006, s. 194-206.

Kroll T., Der Himmel über Berlin - säkulare Mystagogie?, LIT Verlag, Berlin 2008.

MAzZA E., La mistagogia. Le catechesi liturgiche della fine del quarto secolo e il loro metodo, CLV, Roma 1996.

MöDL L., Liturgie und Predigt, „Theologisch-Praktische Quartalschrift” 141(1993), z. 4, s. 198-201.

NADOLSKI B., Mistagogia jako metoda w liturgii, „Collectanea Theologica” 65(1995), z. 3, s. $101-112$.

Nouwen H.J.M., Clowning in Rome. Reflections on Solitude, Celibacy, Prayer, and Contemplation, Image Books, Garden City 1979.

NowAK W., Eucharystia szczytem i źródłem posługi prezbitera a umiejętność jej przewodniczenia, w: Misterium Eucharystii. Teologia - liturgia - ekumenizm. Encyklika Jana Pawła II Ecclesia de Eucharistia, red. tenże, Wydawnictwo Uniwersytetu Warmińsko-Mazurskiego, Olsztyn 2004, s. 101-121.

RAHNER K., Die grundlegenden Imperative für den Selbstvollzug der Kirche in der gegenwärtigen Situation, w: Handbuch der Pastoraltheologie, t. II/1, red. F.X. Arnold, K. Rahner, V. Schurr, L.M. Weber, Herder, Freiburg i.B. 1966, s. 256-276.

RAHNER K., Grundkurs des Glaubens. Einführung in den Begriff des Christentums, Herder, Freiburg i.B. 1977.

RAHNER K., Schriften zur Theologie, t. VII. Zur Theologie des geistlichen Lebens, Benziger, Einsiedeln 1966. 
Ravasi G., Comunicación y Palabra de Dios. Visión bíblica y teológica de la comunicación, w: Evangelización y Comunicación, red. G. Ravasi, J. McDonnell, W. Uranga, San Pablo, Caracas 1994, s. 7-93.

Rueter A.C., Making Good Preaching Better, Liturgical Press, Collegeville 1997.

SEVERUs VON E., Mystagogie heute. Balthasar Fischer zum 80. Geburtstag, „Liturgisches Jahrbuch" 40(1992), z. 3, s. 147-149.

SIMON W., Mystagogie, w: Lexikon der Pastoral, red. K. Baumgartner, P. Scheuchenpflug, Herder, Freiburg i.B. 2002, s. 1173-1177.

WEBER Ch., Firmkatechese als Entdeckungsreise, w: Mystagogische Seelsorge. Eine lebensgeschichtlich orientierte Pastoral, red. S. Knobloch, H. Haslinger, Matthias-Grünewald, Mainz 1991, s. 156-193.

WERNER M., Krise der Korrelation und mystagogisches Handeln, „Info” 2(2003), z. 4, s. 229232.

WOŁOSZKA J., Celebracja sakramentu małżeństwa anamnezą tajemnicy stworzenia, „Anamnesis” 8(2002), z. 4, s. 54-78.

ZINKEVIČIUUTÉ R., Karl Rahners Mystagogiebegriff und seine praktisch-theologische Rezeption, Peter Lang AG, Frankfurt a.M. 2007.

ZulehNer P.M., „Denn du kommst unserem Tun mit deiner Gnade zuvor... ”. Zur Theologie der Seelsorge heute. P.M. Zulehner im Gespräch mit K. Rahner, Patmos, Düsseldorf 1984.

Zulehner P.M., Pastoral: Entriegelung des Menschen, „Theologie der Gegenwart” 23(1980), z. 3, s. 6-11.

ZULEHNER P.M., Von der Versorgung zur Mystagogie. Theologische Implikationen seelsorglicher Praxis, „Lebendige Seelsorge” 33(1982), z. 1, s. 177-182.

\section{MISTAGOGIA EGZYSTENCJALNA KARLA RAHNERA A PRZEPOWIADANIE SŁOWA BOŻEGO}

\section{S t r e s z c z e n i e}

Kościół katolicki po Soborze Watykańskim II coraz więcej uwagi przywiązuje do mistagogii, do czego w znacznej mierze przyczynił się Karl Rahner. Wzywa on do jej praktykowania w duszpasterstwie ze względu na konieczność zmiany sposobu przekazu wiary, która będzie zanikać, jeśli ludzie nie zostaną wprowadzeni w bezpośrednie, osobiste doświadczenie Boga. Dlatego Kościół w swej działalności pastoralnej nie może się ograniczyć do wykładu doktryny chrześcijańskiej, lecz winien wskazywać ludziom drogi prowadzące do życia w zjednoczeniu z Bogiem i towarzyszyć im w osiąganiu pełni człowieczeństwa. Również głoszenie słowa Bożego ma mieć charakter mistagogiczny, czyli odsłaniać ślady obecności Boga w ludzkiej rzeczywistości, odpowiadać na najgłębsze potrzeby duchowe słuchaczy i wspierać ludzi w podejmowaniu decyzji o życiu w zjednoczeniu z Bogiem. Rahnerowska koncepcja mistagogii egzystencjalnej nie neguje potrzeby mistagogii liturgicznej, ale apeluje o jej ścisłe powiązanie z codzienną ludzką egzystencją.

Słowa kluczowe: duszpasterstwo; mistagogia; przepowiadanie; doświadczenie; duchowość chrześcijańska. 